\title{
TEKNIK ISOLASI SENYAWA BIOAKTIF DARI KAPANG YANG BERASAL DARI LINGKUNGAN LAUT
}

\author{
Dedi Noviendri*)
}

\begin{abstract}
ABSTRAK
Pada prinsipnya, teknik isolasi senyawa bioaktif dari kapang yang berasal dari laut mirip dengan teknik isolasi senyawa bioaktif dari invetebrata laut dan juga biota-biota yang ada di lingkungan darat. Namun ada beberapa hal yang berbeda, diantaranya cara isolasi dan pengkulturan terutama pada komposisi media pertumbuhannya, serta cara-cara pemanenannya. Sedangkan cara ekstraksi, fraksinasi, dan purifikasinya sampai mendapatkan suatu senyawa bioaktif yang murni adalah relatif sama. Untuk proses pemisahan dan purifikasi dapat digunakan alat Kromatografi Cair Kinerja Medium (KCKM) dan Kromatografi Cair Kinerja Tinggi (KCKT), serta disertai pengujian kemurnian dengan Kromatografi Lapis Tipis (KLT). Jika dari hasil analisis dengan KCKM atau KCKT memberikan hasil satu puncak (peak) yang tunggal, maka terhadap sampel tersebut dapat dilakukan analisis dengan alat MS, dan hasilnya dibandingkan dengan database untuk menguji apakah senyawa murni yang diperoleh adalah senyawa baru atau bukan. Selanjutnya dengan semua data analisis yang diperoleh dari sampel murni tersebut, yaitu data fisika dan hasil spektrofotometer UV, hasil IR (KBr), MS, NMR 1 dimensi (proton, karbon, dan DEPT), dan NMR 2 dimensi (1H-1H COSY, 13C-1H COSY, HMBC, HMQC, dan NOESY), maka dilanjutkan dengan penentuan struktur molekul (dikenal dengan elusidasi struktur).
\end{abstract}

KATA KUNCI: isolasi senyawa bioaktif, kapang, marine fungus

\section{PENDAHULUAN}

Makroinvertebrata laut yang bersifat sesil seperti spons dan hewan karang dikenal memiliki kandungan senyawa bioaktif yang potensial untuk dikembangkan dalam bidang farmasi. Namun masalah yang muncul dalam eksplorasi senyawa bioaktif dari spons dan hewan karang adalah masalah suplai dan dampak ekologis yang ditimbulkan. Masalah suplai muncul karena rendemen senyawa aktif yang dihasilkan dari spons, misalnya dari berat basah spons Kaliapsis 2109,2 g hanya memperoleh 6,04 g ekstrak kering spons (Setyowati et al., 2007) dan ekstraksi karang sekitar $100 \mathrm{~g}$ berat basah Sarcophyton glaucum hanya menghasilkan puluhan mg senyawa aktif (Wikanta et al., 2007), padahal spons atau hewan karang membutuhkan waktu bertahun-tahun bahkan puluhan tahun untuk mencapai $1 \mathrm{~kg}$ bobot basahnya. Secara ekologis hal ini kurang menguntungkan. Salah satu strategi untuk mengatasi masalah di atas adalah dengan mengisolasi mikroba yang bersimbion dengan spons dan hewan karang kemudian menumbuhkannya di laboratorium. Mikroba yang bersimbiosis dengan spons dan hewan karang menyumbang $60-80 \%$ dari bobot basah inangnya. Salah satu mikroba simbion yang memiliki keragaman tinggi dan mampu tumbuh cepat adalah kapang (marine fungus).
Khusus tentang biodivesitas laut di Indonesia, terdapat 782 spesies alga, 12 spesies lamun, 38 spesies mangrove, 850 spesies spons, 210 spesies karang lunak, serta ribuan spesies berbagai biota lainnya (Dahuri, 2003). Walaupun demikian, kekayaan alam Indonesia yang terkenal ini belum banyak dieksplorasi. Eksplorasi senyawa bioaktif laut, atau sering dikenal sebagai senyawa bioaktif dari laut, baru dilakukan terutama pada invertebrata laut, misalnya spons (Astuti et al., 2005; Li et al., 2005) dan rumput laut (Zhang \& Son, 2006; Zhang \& Son, 2007a; Zhang \& Son, 2007b; Rusman et al., 2007; Kim \& Son, 2007; Ngunyen \& Son, 2007). Sedangkan eksplorasi senyawa bioaktif dari kapang yang berasal dari laut masih jarang dilakukan, sehingga teknik-teknik isolasi senyawa bioaktif dari mikroorganisme yang berasosiasi dengan biota laut tersebut, dalam hal ini kapang, jikapun ada belum begitu berkembang.

Dalam beberapa tahun terakhir ini, orang sudah banyak meneliti potensi mikroorganisme yang berasosiasi dengan biota laut untuk mengisolasi senyawa bioaktif atau senyawa metabolit sekunder yang dihasilkan oleh mikroorganisme tersebut. Kapang yang berasosiasi dengan biota laut atau diisolasi dari lingkungan laut, sangat potensial sebagai mikroorganisme penghasil senyawa bioaktif. Teknik untuk isolasi senyawa bioaktif dari lingkungan yang sering digunakan oleh ahli-ahli kimia bahan alam pada

\footnotetext{
*) Peneliti pada Balai Besar Riset Pengolahan Produk dan Bioteknologi Kelautan dan Perikanan
} 


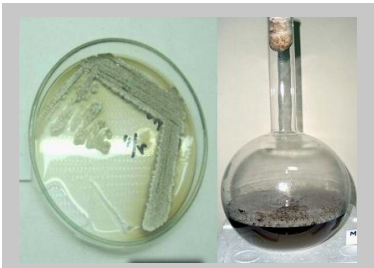

(a)
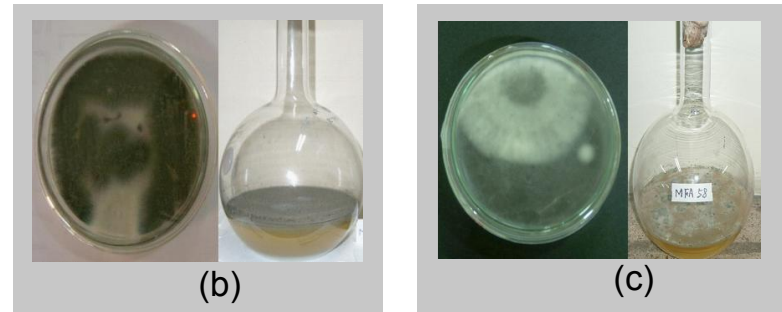

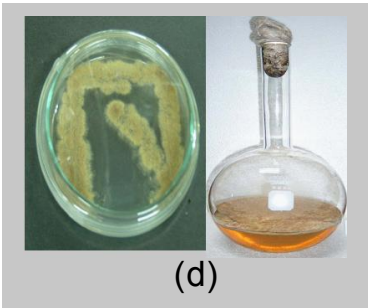

Gambar 1. Beberapa jenis kapang yang telah berhasil diisolasi dari lingkungan laut pada media padat YPG dan media cair SWS; (a) Streptomyces sp. (Rahman et al., 2006), (b) Pseudallescheria sp. (Zhang \& Son, 2006), (c) Myrothecium sp. (Li et al., 2005), dan (d) Aspergillus sp. (Li et al., 2005).

dasarnya semuanya hampir sama. Di Indonesia, teknik-teknik ini sudah biasa dilakukan untuk isolasi senyawa bioaktif dari lingkungan terestrial tanaman tropika yang berpotensi sebagai obat misalnya pada herba meniran (Phyllanthus niruri Linn) (Gunawan et al., 2008), batang Garcinia Balica Miq (Mudjirahmini dan Ersam, 2006), daun pandan wangi (Pandanus amaryllifolius Roxb) (Sukandar et al., 2008a), kulit batang Aglaia disoxylum (Meliaceae) (Sukandar et al., 2008b), buah mahkota dewa [Phaleria macrocarpa (Scheff) Boerl.] (Tambunan dan Simanjuntak, 2006), dan mikroorganisme yang berasal dari lingkungan darat. Pada tulisan ini akan dijelaskan salah satu teknik isolasi senyawa bioaktif dari kapang yang berasal dari lingkungan laut (marine fungus).

\section{KAPANG}

Kapang adalah kelompok mikroba yang tergolong dalam fungi multiseluler yang mempunyai filamen dan pertumbuhannya pada makanan mudah dilihat karena penampakannya yang berserabut seperti kapas. Pertumbuhannya mula-mula akan berwarna putih, tetapi jika sporanya telah timbul akan terbentuk berbagai warna tergantung dari jenis kapang (Gambar 1). Ilmu yang mempelajari mengenai fungi disebut mikologi. Selain kapang, organisme lainnya yang tergolong fungi adalah khamir dan jamur (mushroom). Fungi (jamak) atau fungus (tunggal) adalah suatu organisme eukariotik yang mempunyai ciri-ciri spesifik sebagai berikut: (1) mempunyai inti sel, (2) memproduksi spora, (3) tidak mempunyai klorofil sehingga tidak dapat melakukan fotosintesis, (4) dapat berkembang biak secara seksual maupun aseksual, dan (5) beberapa mempunyai bagian-bagian tubuh berbentuk filamen dengan dinding sel yang mengandung selulosa atau kitin, atau keduanya. Perbedaan utama antara organisme yang tergolong fungi, misalnya antara kapang dan khamir, yaitu kapang adalah fungi yang mempunyai filamen (miselium), sedangkan khamir merupakan fungi sel tunggal tanpa filamen (Fardiaz, 1992).
Pada umumnya, kapang membutuhkan $A_{w}$ minimal lebih rendah dibandingkan dengan khamir dan bakteri untuk pertumbuhannya. Kebanyakan kapang bersifat mesofilik, yaitu tumbuh baik pada suhu kamar. Suhu optimum pertumbuhan untuk kebanyakan kapang adalah sekitar $25-30^{\circ} \mathrm{C}$, tetapi beberapa kapang dapat tumbuh pada suhu $35-37^{\circ} \mathrm{C}$ atau lebih tinggi, misalnya Aspergillus. Beberapa kapang yang telah berhasil diisolasi dari biota laut memiliki suhu optimum sekitar $29^{\circ} \mathrm{C}$, kapang tersebut adalah Streptomyces sp. (Rahman et al., 2006), Pseudallescheria sp. (Zhang \& Son, 2006), Myrothecium sp.(Li et al., 2005), Aspergillus sp. (Li et al., 2005), Penicillium citreonigrum (Rusman et al., 2007), Exophiala (Zhang et al., 2008), dan kapang laut kode B.24 yang telah berhasil diisolasi dari sedimen perairan laut Kepulauan Seribu (Supriyono et al., 2007).

Kemudian semua kapang bersifat aerobik, yaitu membutuhkan oksigen untuk pertumbuhannya. Kebanyakan kapang dapat tumbuh pada kisaran $\mathrm{pH}$

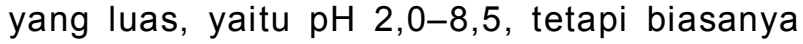
pertumbuhannya akan lebih baik pada kondisi asam atau $\mathrm{pH}$ rendah (Fardiaz, 1992).

\section{ISOLASI KAPANG}

Kapang diisolasi dari sampel lingkungan laut diantaranya dari sedimen, kerang, bulu babi, alga hijau Ulva pertusa (Zhang \& Son, 2007a), Enteromorpha compressa (Li et al., 2005; Kim \& Son, 2007), Agarum cribrosum (Zhang \& Son, 2006; Ngunyen \& Son, 2007), alga merah Hyalosiphonia caespitosa (Zhang \& Son, 2007b), Lomentaria catenata (Li et al., 2005), alga coklat Sargassum horneri (Ngunyen \& Son, 2007), spons Halichondria panacea (Zhang \& Son, 2007b), Pseudoceratina purpurea (Rusman et al., 2007), dan Petrosia sp. (Astuti et al., 2005). Saat ini kelompok peneliti Bioteknologi Balai Besar Riset Pengolahan Produk dan Bioteknologi Kelautan dan Perikanan sedang melakukan riset isolasi senyawa bioaktif dari kapang yang bersimbiosis dengan spons, namun spons yang digunakan belum teridentifikasi. 
Isolasi kapang dilakukan dengan menempatkan sampel pada media selektif untuk kapang. Media yang dapat digunakan untuk isolasi kapang ada berbagai jenis yaitu potato dextrose agar (PDA) (Suryono et al., 2002; Nugroho et al., 2003), peptone glucose fluconazole agar (PGFA) (Randhawa et al., 2005), potato carot agar, pentachloronitrobenzene agar, rose bengal medium, yeast malt agar (Demain \& Solomon, 2986), yeast peptone glucose (YPG) (Li et al., 2005; Li et al., 2006; Rahman et al., 2006 dan Zhang \& Son, 2006; Ngunyen \& Son, 2007; Zhang et al., 2008), dan media lainnya. Namun dari sekian banyak media yang dapat digunakan untuk isolasi kapang, yang akan dijelaskan di sini hanya media YPG.

Mula-mula sampel ditempatkan pada media YPG, lalu media ditempatkan di dalam inkubator (untuk skala kecil) atau di dalam suatu ruangan khusus (untuk skala besar) yang dijaga kondisi suhu dan kelembabannya, dan setelah itu dibiarkan beberapa hari. Setelah beberapa hari, berbagai kapang akan tumbuh pada media YPG tersebut, lalu dilakukan pemurnian secara berulang-ulang dengan cara menumbuhkan kembali dengan media yang sama sampai didapatkan kultur kapang yang tunggal. Kultur tunggal kapang ini dapat langsung digunakan dan sebagian yang lain dapat disimpan pada gliserol dengan kondisi suhu penyimpanan $-80^{\circ} \mathrm{C}$. Kultur tunggal ini kemudian ditumbuhkan ke dalam media cair YPM yang terdiri atas yeast extract, pepton, dan manitol dengan volume kerja $10 \mathrm{ml}$, lalu diinkubasi pada suhu tertentu, biasanya $28-29^{\circ} \mathrm{C}$ (Li et al., 2005; Li et al., 2006; Rahman et al., 2006 dan Zhang \& Son, 2006; Ngunyen \& Son, 2007; Zhang et al., 2008) selama 3 sampai 4 hari dalam kondisi statis. Setelah beberapa hari (3 sampai 4 hari), kultur kapang dipindahkan secara aseptik ke dalam media cair SWS yang terdiri atas soytone, water (dalam hal ini air laut), dan soluble starch dengan volume kerja $1 \mathrm{~L}$, lalu diinkubasi pada suhu $28-29^{\circ} \mathrm{C}$ selama $25-30$ hari dalam kondisi statis (Zhang \& Son, 2007a). Pertumbuhan kapang biasanya berjalan lambat bila dibandingkan dengan pertumbuhan khamir dan bakteri. Oleh karena itu, jika kondisi pertumbuhan memungkinkan semua mikroorganisme untuk tumbuh, kapang biasanya kalah dalam kompetisi dengan khamir dan bakteri. Tetapi jika kapang dapat tumbuh, pertumbuhannya yang ditandai dengan pembentukan miselium dapat berlangsung dengan cepat (Fardiaz, 1992).

\section{ISOLASI BAHAN AKTIF}

\section{Panen dan Ekstraksi}

Setelah kapang ditumbuhkan pada media cair SWS selama 25-30 hari dalam kondisi statis, maka kapang telah tumbuh dengan pesatnya, yang ditandai dengan terbentuknya miselium, media pertumbuhannya telah berubah warna, dan warna yang terbentuk tergantung dari jenis kapang yang ditumbuhkan (Gambar 1). Beberapa kapang mengeluarkan suatu senyawa metabolit sekunder. Senyawa ini biasanya dikeluarkan oleh suatu kapang untuk pertahanan diri dan dapat menghambat pertumbuhan organisme lain (Fardiaz, 1992). Senyawa metabolit sekunder dari kapang misalnya Penisilin yang diproduksi oleh Penicillium chrysogenum dan Clavasin yang diproduksi oleh Aspergillus clavatus (Fardiaz, 1992). Sedangkan senyawa metabolit sekunder yang telah berhasil diisolasi dari kapang yang bersimbiosis dengan biota laut diantaranya adalah sebagai berikut: Redoksitrinin dari Penicillium sp. (Zhang et al., 2007a), Fusrielin A dari Aspergillus sp. (Ngunyen \& Son, 2007), Botrititon dari Botrytis sp. (Zhang \& Son, 2007), Dihidroksifumitremorgin C, Fumitremorgin C, Brevianamid F dari Pseudallescheria sp. (Zhang et al., 2007b), dan Benzodiazepin dari Exophiala (Zhang et al., 2008).

Setelah kapang tumbuh dengan baik selama 25-30 hari tersebut, maka dapat dilakukan proses pemanenan. Proses ini akan memperoleh dua bagian penting yang akan digunakan untuk isolasi senyawa organik, atau senyawa bioaktif yang dihasilkan oleh kapang, yaitu bagian broth dan miselium. Cara pemanenan sebagai berikut, pertama sampel kapang yang terdiri atas broth dan miselium disaring dengan menggunakan kain kasa. Filtrat (broth) langsung ditampung di dalam corong pisah, sedangkan miseliumnya tertinggal di kain kasa. Miselium ini segera disimpan di dalam aluminium foil tertutup dan disimpan di dalam freezer untuk digunakan pada uji selanjutnya. Setelah disimpan dalam freezer selama 1 malam, kemudian dilakukan ekstraksi menggunakan pelarut $\left(\mathrm{MeOH}: \mathrm{CH}_{2} \mathrm{Cl}_{2}=1: 1\right)$. Sedangkan broth diekstrak dengan menggunakan pelarut etil asetat (EtOAc), (Li et al., 2005; Li et al., 2006; Rahman et al., 2006 dan Zhang \& Son, 2006; Ngunyen \& Son, 2007; Son, 2007; Zhang et al., 2008), yang tujuannya adalah untuk mendapatkan senyawa non-polar (senyawa target yang baru) yang biasanya banyak terdapat pada kapang. Broth ini ditambahkan etil asetat (EtOAc) dengan perbandingan ( $1: 1)$ dalam corong pisah, lalu dikocok kuat-kuat, dan dilakukan berulang, kurang lebih tiga kali. Setelah itu, corong pisah didiamkan beberapa waktu sampai benar-benar memisah membentuk dua lapisan yang akan dipisahkan. Lapisan atas adalah broth dalam EtOAc yang di dalamnya terdapat metabolit sekunder serta lapisan bawah adalah air bersama media dan kotoran lainnya. Fase atasnya diambil dan digunakan untuk tahap selanjutnya, sedang fase bawahnya dibuang karena merupakan kontaminan yang tidak diharapkan. Lapisan atas (broth) ini selanjutnya ditambahkan 
dengan sodium sulfat anhidrat $2 \%(\mathrm{~b} / \mathrm{v})$ untuk menghilangkan sisa air yang masih terdapat pada broth. Setelah benar-benar bebas air yang ditandai dengan menggumpalnya sodium sulfat anhidrat, maka broth selanjutnya dipindahkan ke dalam labu evaporator untuk proses pengeringan, dengan evaporasi. Proses evaporasi dihentikan sampai diperoleh broth yang benar-benar kering, lalu ditimbang dan siap untuk uji selanjutnya (Gambar 2).

Terhadap kedua ekstrak (ekstrak miselium dan broth) yang diperoleh, selanjutnya dilakukan pengujian (assay) terlebih dahulu untuk menentukan apakah ekstrak yang diperoleh tersebut aktif atau tidak. Jika seandainya ekstrak yang diperoleh tidak aktif, maka pengujian tidak dilanjutkan. Namun, jika ekstrak yang diperoleh tersebut bersifat aktif (merupakan suatu senyawa bioaktif), maka tahap selanjutnya yang dilakukan adalah fraksinasi ekstrak tersebut dengan menggunakan kromatografi kolom $\mathrm{SiO}_{2}$ (Li et al., 2005; Li et al., 2006; Rahman et al., 2006 dan Zhang \& Son, 2006; Ngunyen \& Son, 2007; Son, 2007; Zhang et al., 2008). Kolom $\mathrm{SiO}_{2}$ (bersifat fase normal) ini dipilih karena beberapa hal, diantaranya harganya relatif murah. Kemudian dengan kolom $\mathrm{SiO}_{2}$ ini bisa lebih banyak memisahkan/mendapatkan senyawa (mulai dari senyawa non-polar sampai polar). Senyawa dapat dipisahkan menurut derajat kepolarannya dengan menggunakan pelarut (sebagai fase geraknya) mulai dari n-heksana (bersifat non- polar) sampai metanol (bersifat polar). Sehingga, senyawa non-polar (senyawa target yang baru) juga dapat dipisahkan dan diperoleh dengan baik. Adapun jenis assay yang digunakan dalam pengujian ini adalah bermacam-macam, tergantung dengan yang diinginkan dan target dari peneliti yang akan bekerja untuk menemukan suatu senyawa bioaktif baru tersebut.

\section{Fraksinasi}

Pada tahap fraksinasi ini akan dijelaskan kromatografi kolom $\mathrm{SiO}_{2}$ dan kromatografi lapis tipis sebagai pemandu isolasi.

\section{Kromatografi kolom $\mathrm{SiO}_{2}$}

Setelah dilakukan proses pemanenan dan ekstraksi broth dengan pelarut EtOAc dan miselium dengan pelarut (metanol: $\mathrm{CH}_{2} \mathrm{Cl}_{2}=1: 1$ ), maka selanjutnya dilakukan pemisahan/fraksinasi dengan menggunakan kolom silika Column Chromatography (open column) atau yang dikenal dengan $\mathrm{SiO}_{2}-$ CC (Li et al., 2005; Li et al., 2006; Rahman et al., 2006; Zhang \& Son, 2006; Ngunyen \& Son, 2007; Son, 2007; Zhang et al., 2008) terhadap kedua sampel tersebut. Khusus untuk miselium, sebelum dilakukan tahap selanjutnya harus dilakukan terlebih dahulu proses desalting untuk menghilangkan garam-garam yang dikandungnya.

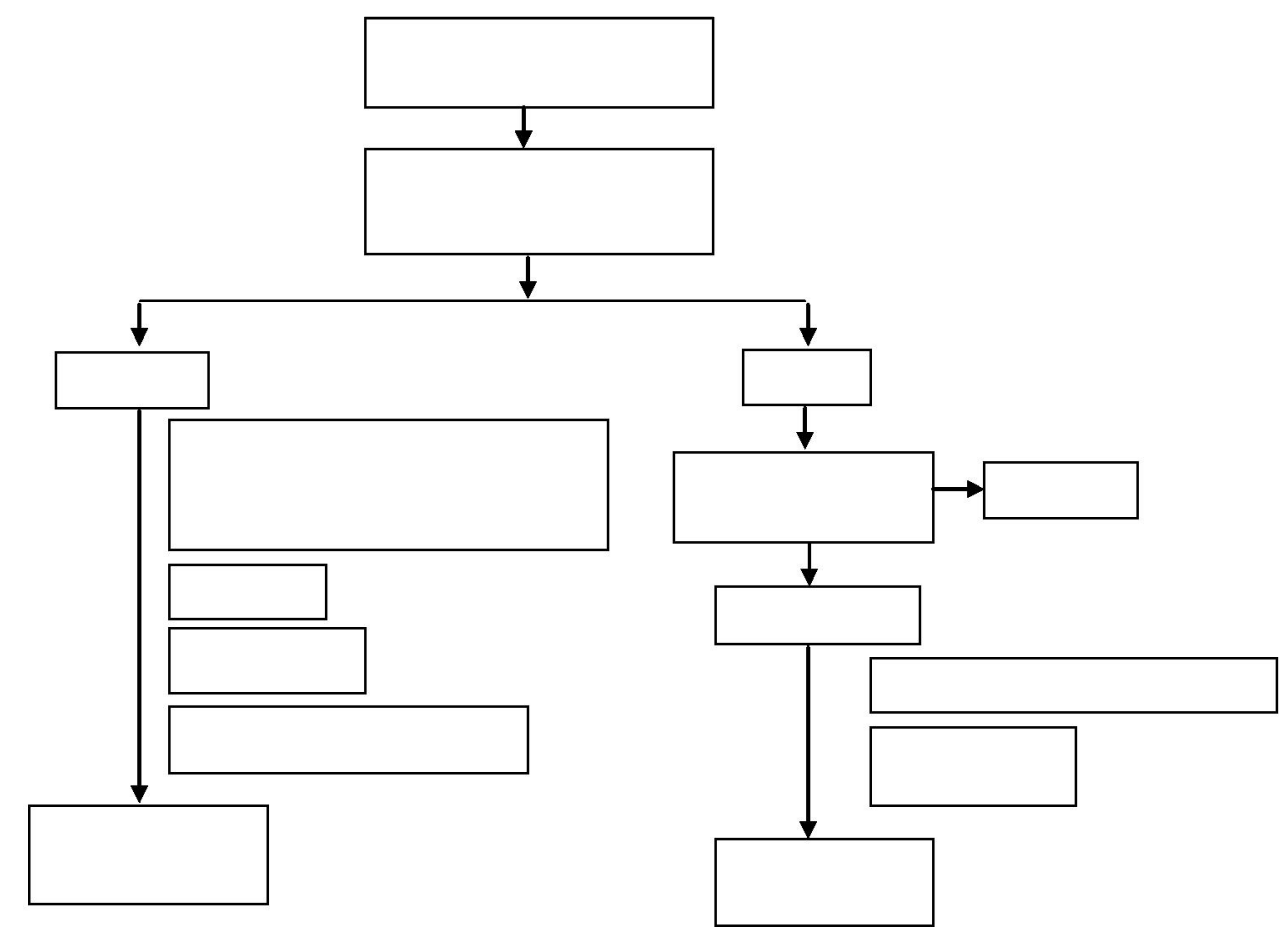

Gambar 2. Diagram alir tahap pemanenan dan ekstraksi miselium dan broth dari kapang laut pada Li et al., 2005; Li et al., 2006; Rahman et al., 2006; Zhang \& Son, 2006; Ngunyen \& Son, 2007; Son, 2007; dan Zhang et al., 2008. (Keterangan: M:C=Metanol: $\mathrm{CH}_{2} \mathrm{Cl}_{2}$ ) 
Adapun cara-cara preparasi kolom dan fraksinasi menggunakan kolom Si terhadap sampel broth dan miselium adalah sebagai berikut (Son, 2007):

1. Disiapkan tabung kolom yang kering dan bersih (jangan sampai ada air sedikitpun, karena hal tersebut dapat menimbulkan gelembung pada kolom Si).

2. Dimasukkan kapas bersih, lalu dimasukan silika gel juga ke dalam kolom dengan rasio antara sampel yang akan dielusi dengan silika gel adalah 1: 50 70, biasanya 1:50, atau tergantung ukuran panjang kolom yang digunakan.

3. Silika gel dicampur dengan n-heksana, lalu campuran tersebut dimasukkan perlahan-lahan ke dalam kolom (jangan sampai ada gelembung).

4. Dibiarkan beberapa saat sampai silika gel memadat di dalam tabung, bila perlu dibantu dengan cara memukul-mukul bagian luar kolom dengan karet untuk mempercepat proses pemadatan.

5. Setelah padat, ke dalam kolom dimasukkan kapas bersih lagi secukupnya, lalu dibilas/ dibasahi dengan $\mathrm{n}$-heksana (ini dilakukan untuk mencegah percampuran antara silika gel dengan sampel secara langsung saat sampel dimasukkan).

6. Sampel siap dimasukkan, dielusi mulai dengan pelarut non-polar (n-heksana) sampai pelarut polar (Metanol).

\section{KROMATOGRAFI LAPIS TIPIS (KLT) SEBAGAI PEMANDU ISOLASI}

Setelah selesai fraksinasi menggunakan kolom silika terbuka, maka dilanjutkan dengan proses evaporasi untuk pengeringan terhadap semua fraksi yang diperoleh (baik dari sampel miselium maupun sampel broth), lalu semua fraksi ditimbang. Kemudian terhadap semua fraksi ini dilakukan uji lebih lanjut untuk mendapatkan suatu senyawa yang benar-benar murni (pure). Untuk memudahkan tahap isolasi dan arah pekerjaan selanjutnya maka perlu mengikuti suatu panduan isolasi dalam mendapatkan senyawa bioaktif target. Panduan isolasi ini tergantung dari tujuan peneliti yang akan melakukan pekerjaan isolasi senyawa bioaktif tersebut.

Biasanya ada dua cara yang digunakan untuk panduan tahap isolasi. Pertama, assay guide isolation, yaitu tahap isolasi yang dilakukan berdasarkan atau dipandu oleh uji-uji yang dilakukan. Isolasi suatu senyawa bioaktif akan mengacu pada suatu assay (uji) sesuai dengan target senyawa yang diinginkan, misalnya uji anti bakteri (Rusman et al., 2007; Gunawan et al., 2008), anti penuaan, anti ultraviolet A (Zhang et al., 2008), anti kanker dengan metode uji MTT [3-(4,5-dimetiltiazol-2-il)-2, 5difeniltetrazolium bromida] (Astuti et al., 2005; Setyowati et al., 2007), uji DPPH (1,1- difenil-2pikrilhidrazil) (Li et al., 2006a; Li et al., 2006b; Mudjirahmini \& Ersam, 2006), atau uji-uji yang lainnya. Jadi disetiap tahap fraksinasi yang dilakukan, sampelnya selalu diuji sesuai target senyawa yang diinginkan. Pekerjaan ini dilakukan kontinyu, sampai diperoleh suatu target senyawa yang diinginkan murni (pure). Kedua, TLC guide isolation, yaitu tahap isolasi yang dilakukan berdasarkan hasil TLC atau kromatografi lapis tipis (KLT) (Gambar 3). Ini berdasarkan target spot KLT yang diperoleh dan pekerjaanya juga dilakukan secara kontinyu sampai diperoleh suatu spot dari target senyawa yang diinginkan benar-benar murni (Ritmaleni \& Nurcahyani, 2006; Setyowati et al., 2007). Namun hasil KLT yang telah memberikan satu spot ini perlu juga dilakukan pengujian kemurnian dengan KCKT (Swantara et al., 2007) atau dengan GC-MS (Gunawan et al., 2008). Hal ini disebabkan oleh satu spot hasil KLT tersebut dapat memberikan dua puncak (peak) atau lebih (Gunawan et al., 2008).

Pada KLT ini, fase diam (fase stasioner) berupa lapisan yang seragam pada bidang datar yang didukung oleh lempeng kaca, pelat aluminium, atau

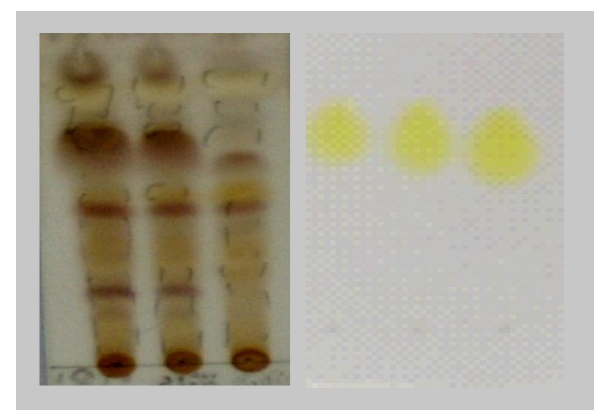

Gambar 3. Kromatogram dari hasil suatu sampel senyawa organik menggunakan KLT; (a) contoh sampel yang belum murni dan (b) contoh sampel yang sudah murni. 
pelat plastik, berbeda dengan kromatografi kolom yang fase diamnya diisikan atau dikemas di dalam kolom. Meskipun demikian, KLT ini dapat dikatakan sebagai bentuk terbuka dari kromatografi kolom. Fase diam yang digunakan dalam KLT merupakan penjerap berukuran kecil dengan diameter partikel antara 10$30 \mu \mathrm{m}$. Penjerap yang paling sering digunakan adalah silika dan serbuk selulosa (Rohman, 2007).

Menurut Rohman (2007), fase gerak (eluen) pada KLT dapat dipilih dari pustaka, namun lebih sering dengan mencoba-coba karena waktu yang diperlukan hanya sebentar. Sistem yang paling sederhana adalah campuran dua pelarut organik karena daya elusi campuran kedua pelarut ini dapat dengan mudah diatur sedemikian rupa, sehingga pemisahan dapat terjadi secara optimal. Beberapa petunjuk dalam memilih dan mengoptimasi fase gerak adalah (Rohman, 2007):

1. Fase gerak harus mempunyai kemurnian yang sangat tinggi, karena KLT merupakan teknik yang sensitif.

2. Daya elusi fase gerak harus diatur sedemikian rupa sehingga nilai Rf (Gambar 4) terletak antara 0,2-0,8 untuk memaksimalkan pemisahan.

3. Untuk pemisahan dengan menggunakan fase diamnya polar seperti silika gel, maka polaritas fase gerak akan menentukan kecepatan migrasi solut (zat terlarut), yang berarti juga menentukan nilai Rf. Penambahan pelarut yang sedikit polar seperti dietil eter ke dalam pelarut non polar seperti metil benzena akan meningkatkan nilai Rf secara signifikan.

4. Solut-solut polar lebih baik menggunakan campuran pelarut sebagai fase geraknya, seperti campuran air dan metanol dengan perbandingan tertentu.

Reagen (pereaksi) yang digunakan sebagai penampak bercak (spot) dalam KLT dapat dibedakan menjadi 2, yaitu pereaksi umum yang berlaku untuk hampir semua senyawa organik (Tabel 1) dan pereaksi selektif yang hanya mendeteksi jenis atau golongan senyawa tertentu (Tabel 2).

Untuk mendapatkan senyawa murni, diperlukan tahap pemisahan dan pemurnian dengan menggunakan HPLC atau lebih dikenal dengan kromatografi cair kinerja tinggi (KCKT) dan juga MPLC atau lebih dikenal dengan kromatografi cair kinerja medium (KCKM). Kemudian dari sampel yang telah diperoleh berupa senyawa murni, yang ditandai dengan hasil KLT memberikan hasil satu spot (Ritmaleni \& Nurcahyani, 2006; Setyowati et al., 2007), dan hasil analisis dengan KCKM atau KCKT memberikan hasil satu puncak (peak) yang tunggal. Selanjutnya terhadap sampel tersebut dilakukan analisis dengan alat MS atau yang dikenal dengan spektroskopi massa (SM) untuk mengetahui bobot molekul (BM) dan ion fragmen dari hasil fragmentasi senyawa (Ritmaleni \& Nurcahyani, 2006). Hasil MS dibandingkan dengan database/pustaka, untuk menguji apakah senyawa murni yang diperoleh adalah senyawa baru atau tidak. Hal ini penting, karena bagi peneliti di bidang kimia bahan alam, mendapatkan suatu senyawa baru adalah sesuatu hal yang menjadi prioritas. Ada empat prioritas yang digunakan oleh peneliti di bidang kimia bahan alam dalam mendapatkan senyawa bioaktif. Menurut Son (2007) keempat prioritas tersebut adalah (1) senyawa baru dan bersifat aktif, (2) senyawa baru namun tidak aktif, (3) senyawa sudah dikenal namun aktif, dan (4) senyawa sudah dikenal dan tidak aktif. Prioritas terakhir inilah yang paling tidak disukai oleh ahli-ahli kimia bahan alam dalam proses pencarian dan isolasi senyawa bioaktif.

Jika sampel murni yang diperoleh diduga adalah suatu senyawa baru, maka proses analisisnya dilanjutkan dengan menggunakan FTIR (Fourier Transform-Infra Red) untuk menentukan gugus fungsi (Januar et al., 2007) yang menyusun senyawa baru tersebut dan juga jumlah atom karbon dan proton penyusun senyawa baru tersebut dengan menggunakan NMR (Nucleus Magnetic Resonance).

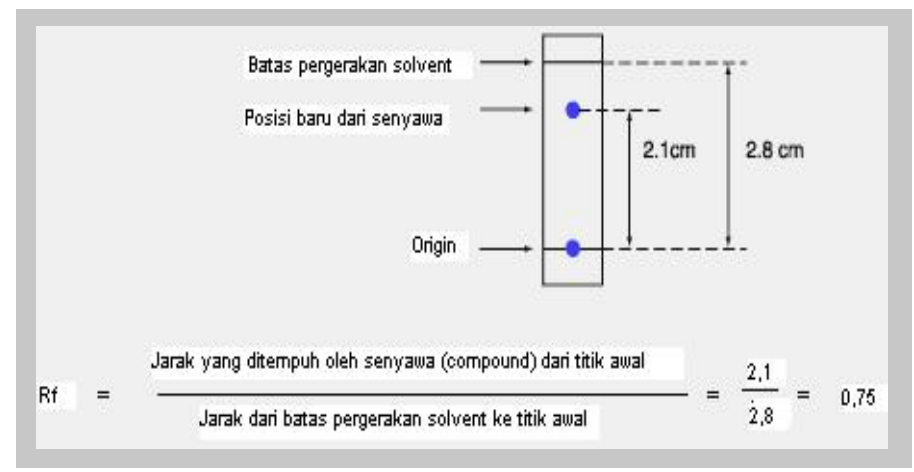

Gambar 4. Cara menentukan nilai Rf dari suatu hasil KLT (Anon., 2008). 
Tabel 1. Beberapa pereaksi umum yang digunakan pada KLT

\begin{tabular}{lll}
\hline Metode deteksi & Warna bercak solut & \multicolumn{1}{c}{ Penggunaan } \\
\hline $\begin{array}{l}\text { Asam fosfomolibdat } \\
+ \text { pemanasan }\end{array}$ & Biru gelap & $\begin{array}{l}\text { Beberapa senyawa } \\
\text { organik }\end{array}$ \\
$\begin{array}{l}\text { Asam sulfat pekat }+ \\
\text { pemanasan }\end{array}$ & Hitam kecoklatan & $\begin{array}{l}\text { Semua senyawa } \\
\text { organik }\end{array}$ \\
Uap iodium & Coklat & $\begin{array}{l}\text { Beberapa senyawa } \\
\text { organik }\end{array}$ \\
\hline
\end{tabular}

Sumber: Rohman (2007).

Tabel 2. Beberapa pereaksi spesifik yang digunakan pada KLT

\begin{tabular}{|c|c|c|}
\hline Metode deteksi & Warna bercak solut & Penggunaan \\
\hline Ninhidrin & Pink ke ungu & $\begin{array}{l}\text { Asam-asam amino } \\
\text { dan amina }\end{array}$ \\
\hline $\begin{array}{l}\text { 2,4-dinitrofenil } \\
\text { hidrazon }\end{array}$ & Oranye/merah & $\begin{array}{l}\text { Senyawa-senyawa } \\
\text { karbonil }\end{array}$ \\
\hline $\begin{array}{l}\text { Bromokresol } \\
\text { hijau/biru }\end{array}$ & Kuning & Asam-asam organik \\
\hline 2,7-fluoresein & Kuning kehijauan & Senyawa organik \\
\hline Vanilin/asam sulfat & Merah/hijau/pink & Alkohol/keton \\
\hline Rhodamin-B & Berfluoresensi merah & Lemak \\
\hline $\begin{array}{l}\text { Anisaldehida/antimon } \\
\text { kloida }\end{array}$ & Berbagai macam & Steroid \\
\hline Difenilamina/seng & Berbagai macam & Pestisida \\
\hline
\end{tabular}

Jumlah atom karbon ditentukan dengan ${ }^{13} \mathrm{C}-\mathrm{NMR}$ dan jumlah atom proton dengan ${ }^{1} \mathrm{H}-\mathrm{NMR}$. Selanjutnya dengan semua data analisis yang diperoleh dari sampel murni tersebut, yaitu data fisika dan hasil spektrofotometer UV, hasil IR (KBr), MS, NMR 1 dimensi (proton, karbon, dan DEPT) (Mudjirahmini \& Ersam, 2006), serta NMR 2 dimensi seperti $1 \mathrm{H}-1 \mathrm{H}$ COSY, 13C-1H COSY, HMBC (Tambunan dan Simanjuntak, 2006), HMQC (Sukandar et al., 2007), dan NOESY (Rusman et al., 2007). Setelah data didapatkan, maka dapat dilanjutkan dengan penentuan struktur molekul (dikenal dengan elusidasi struktur). Tahap ini merupakan tahap yang paling sulit dan menentukan dari semua tahap yang dilakukan untuk mendapatkan dan menentukan struktur senyawa baru.

\section{PENUTUP}

Teknik isolasi senyawa bioaktif dari kapang yang berasal dari lingkungan laut ini bisa digunakan dan dikembangkan di Indonesia, mengingat semua bahan dan peralatan yang digunakan sudah banyak tersedia. Namun, untuk mendapatkan hasil terbaik perlu dilakukan penyempurnaan metode-metode yang digunakan, selain itu yang tidak kalah pentingnya kemampuan para penggunanya dalam menggunakan alat-alat yang relatif canggih perlu diasah dan ditingkatkan terus. Kemudian untuk mendapatkan kondisi terbaik isolasi senyawa bioaktif dari kapang tersebut, para pengguna dapat melakukan modifikasimodifikasi dalam setiap tahap yang digunakan. Modifikasi ini dapat dilakukan pada media pengkulturan terutama jenis dan komposisi media, cara pemanenan, jenis pelarut, dan kolom yang digunakan untuk fraksinasi.

\section{UCAPAN TERIMA KASIH}

Terima kasih diucapkan kepada Muhammad Nursid, M.Si yang telah meluangkan waktunya diawal 
penulisan ini untuk memberikan kritikan dan masukan demi kesempurnaan tulisan ini.

\section{DAFTAR PUSTAKA}

Astuti, P., G., Alam., M.S.Hartati., D. Sari., dan S. Wahyuono. 2005. Uji Sitotoksik Senyawa Alkaloid dari Spons Petrosia sp: Potensial Pengembangan Sebagai Antikanker. Maj Farm Indo. 16(1): 58-62.

Dahuri, R. 2003. Keanekaragaman Hayati Laut. PT. Gramedia. Pustaka Utama. 412 pp.

Demain, A.L. and Solomon, N.A. 1986. Manual of Industrial Microbiology and Biotechnology. American Society for Microbiology, Washington, D.C. $466 \mathrm{pp}$.

Fardiaz, S. 1992. Mikrobiologi Pangan 1. Gramedia Pustaka Utama, Jakarta. 308 pp.

Gunawan, I.W.G., I.G.A.G. Bawa., dan N.L. Sutrisnayanti. 2008. Isolasi dan Identifikasi Senyawa Terpenoid yang Aktif Antibakteri pada Herba Meniran (Phyllanthus niruri Linn). J. Kimia. 2(1): 31-39.

Januar, H. I., Patmaesari, L., Wikanta, T., dan Chasanah, E. 2007. Analisis Dereplikasi Substansi Bioaktif Fraksi Polar Petrosia sp. Dari Perairan Kepulauan Seribu. JPB, Perikanan. 2(2): 129-136.

Khong, T and Son, B.W. 2006. Diketopiperazine Alkaloid from the Marine-Derived Fungus Pseudallescheria sp. Prensented at Lab meeting in Natural Product Chemistry Laboratory. Department of Chemistry, Pukyong National University, Busan. Korea. 8 pp.

Kim, Y. H and Son, B.W. 2007. Biological Synthesis of Polyketides from 6-n-pentyl-á-pyrone by Streptomyces sp. Prensented at Lab meeting in Natural Product Chemistry Laboratory. Department of Chemistry, Pukyong National University, Busan. Korea. $24 \mathrm{pp}$.

Li, X., Choi, H. D., and Son, B. W. 2005. Bioactive Polyketides from a Marine Isolate of the Fungus Myrothecium. Prensented at Lab meeting in Natural Product Chemistry Laboratory. Department of Chemistry, Pukyong National University, Busan. Korea. $15 \mathrm{pp}$.

Li, X., S.K. Kim., J.S. Kang., H.D. Choi, and B.W. Son. 2006. Radical Scaving Hydroxyphenyl Ethanoic Acid Derivative from a Marine-Derivative Fungus. J. Microbiol. Biotechnol. 16(4): 637-638.

Li, Y., Li, X., and Son, B. W. 2005. Diketopiperazine Alkaloid from the Marine-Derived Fungus Aspergillus sp. Prensented at Lab meeting in Natural Product Chemistry Laboratory. Department of Chemistry, Pukyong National University, Busan. Korea. $18 \mathrm{pp}$.

Mudjirahmini, D dan T. Ersam. 2006. 4-Fenilkumarin pada Fraksi Polar Ekstrak Etil Asetat dari Batang Garcinia balica Miq. Seminar Nasional Kimia VII di Surabaya. 8 Agustus 2006. 9 pp.

Ngunyen, P. H and Son, B. W. 2006. Two Antimicrobial Polyketides from a Marine-Derived Fungus. Prensented at Lab meeting in Natural Product Chemistry Laboratory. Department of Chemistry, Pukyong National University, Busan. Korea. 14 pp.
Nugroho, T.T., M. Ali., C. Ginting., Wahyuningsih., A. Dahliaty., S. Devi, dan Y. Sukmarisa. 2003. Isolasi dan Karakterisasi sebagian Kitinase Trichoderma viride TNJ63. J. Nat. Indo. 5(2): 101-106.

Rahman, A., Li, X., and Son, B. W. 2006. Biological Synthesis of the Oxidized Terreusinone by Streptomyces sp. Prensented at Lab meeting in Natural Product Chemistry Laboratory. Department of Chemistry, Pukyong National University, Busan. Korea. $10 \mathrm{pp}$.

Randhawa, H.S., T. Kowshik., K.P. Sinha., R.S. Sandhu, and A. Chowdhary. 2005. Peptone glucose fluconazole agar, a selective medium for rapid and enchanced isolation of Aspergillus fumigatus from aqueous suspensions and sputum seeded with Candida albicans. Current Sci. 88(3): 449-454.

Ritmaleni dan W. Nurchayani. 2006. Sintesis 4-fenil-3,4tetrahidro-indeno [2,1]-pirimidin-2-on (LR-1). Maj. Farm Indo. 17(3): 149-155.

Rohman, A. 2007. Kimia Farmasi Analisis. Pustaka Pelajar, Yogyakarta. 485 pp.

Rusman, Y., P. Proksch., and R. Ebel. 2007. Isolasi dan Aktivitas Biologi Senyawa Meroterpen dari Jamur Laut Penicillium citronigrum. Prosiding Seminar Nasional Kimia 2007. Departemen Kimia FMIPA-UI (Program Hibah Kompetisi-A3). Himpunan Kimia Indonesia (HKI).

Suryono, A., Martina, dan A.M. Chainulfifah. 2002. Isolasi dan Karakterisasi Jamur Penghasil Inulinase yang Tumbuh pada Umbi Dahlia (Dahlia variabilis). J. Nat. Indo. 4(2): 171-177.

Setyowati, E.P., U.A. Jenie., Sudarsono., B. Kardono., R. Rahmat, dan E. Meiyanto. 2007. Isolasi Senyawa Sitotoksik Spons Kaliapsis. Maj Farm Indo. 18(4): 183-189.

Son, B. W. 2007. A short communication.

Sukandar, D., S. M. Chairul, dan Nurlaela. 2007. Elusidasi Struktur Kimia Senyawa Bioaktif Pengendali Serangga Ulat Kubis Dari Kulit Batang Aglaia Disoxylum (Meliaceae). J. Valensi. 1(1):7-13.

Sukandar, D., S. Hermanto, dan E. Lestari. 2008. Uji Toksisitas Ekstrak Daun Pandan Wangi (Pandanus amaryllifolius Roxb.) dengan Metode Brine Shrimp Lethality Test (BSLT). J. Valensi. 1(2): 63-70.

Supriyono, A., Y. Rusman., S. Kusumaningrum, dan E. Rofaani. 2007. Isolasi Senyawa aktif Meleagrine dari Kapang Laut kode B.24 yang Diisolasi dari Redimen Perairan Laut Kepulauan Seribu. Prosiding Seminar Nasional Kimia 2007. Departemen Kimia FMIPA-UI (Program Hibah Kompetisi-A3). Himpunan Kimia Indonesia $(\mathrm{HKI})$.

Swantara, I.M.D., A. Supriyono, dan M. Trinoviani. 2007. Isolasi dan Identifikasi Senyawa Toksik pada Spons dari Perairan Pili Sulat-Lombok. J. Kimia. 1(2): 6769.

Tambunan, R.M dan P. Simanjuntak. 2006. Penentuan Struktur Kimia Antioksidan Benzofenon glikosida dari Ekstrak n-Butanol Buah Mahkota Dewa [Phaleria macrocarpa (Scheff) Boerl.]. Maj Farm Indo. 17(4): 184-189. 
Wikanta, T., Y. A. Zakaria, D. Ratih, dan M. Nursid. Uji Aktivitas Sitotoksik ekstrak karang lunak Sarcophytonglaucum (Quoy \& Gaimard) Terhadap Sel Lestari Tumor Hela. JPB. KP. 2(1): 69-80.

Zhang, D \& Son, B. W. 2006. Antibacterial Dioxopiperazine Alkaloids from the Marine-derived Fungus Pseudallescheria. Prensented at Lab meeting in Natural Product Chemistry Laboratory. Department of Chemistry, Pukyong National University, Busan. Korea. 12 pp.

Zhang, D \& Son, B. W. 2006. The metabolites from a Marine-Derived Fungus Aspergillus sp. Prensented at Lab meeting in Natural Product Chemistry Laboratory. Department of Chemistry, Pukyong National University, Busan. Korea. 28 pp.

Zhang, D \& Son, B. W. 2007a. Citrinin from a Marine-Derived Fungus Aspergillus sp. Prensented at Lab meeting in Natural Product Chemistry Laboratory. Department of Chemistry, Pukyong National University, Busan. Korea. 9 pp.
Zhang, D \& Son, B. W. 2007b. Chemical Studies on the Bioactive Metabolites from Marine-Derived Fungi MFB604 \& MFC353. Prensented at Lab meeting in Natural Product Chemistry Laboratory. Department of Chemistry, Pukyong National University, Busan. Korea. 46 pp.

Zhang, D., Li, X., Kang, J. S., Choi, H.D., Jung, J. H., and Son, B.W. 2007a Redoxcitrinin, a biogenetic precursor of citrinin from marine isolate of fungus Penicillium sp. J.Microbiol. Biotechnol. 17, 865-867.

Zhang, D., Noviendri, D., Nursid., M. Dong, X., and Son, B.W. 2007b. 12,13-Dihydroxyfumitremorgin C, Fumitremorgin $\mathrm{C}$, and Brevianamide $\mathrm{F}$, Antibacterial Diketopiperazine Alkaloids from the Marine-Derived Fungus Pseudallescheria sp. J. Nat Prod. Sci. 13(3):251-254.

Zhang, D., X. Yang., J.S. Kang., H.D. Choi., and B.W. Son. 2008. Circumdatin I, a New Ultraviolet-A Protecting Benzodiazepine Alkaloid from a Marine Isolate of the Fungus Exophiala. J. Antibiot. 61(1): 40-42. 